\title{
Investigating DNA Damage Mechanism Induced by Monosodium Glutamate and Associated DNA Repair Cell Machinery: A Literature Review
}

Novin Aghaei, BSc Student [1], Teodora Grigorescu, BSc Student [1], Niayesh Katani, BSc
Student [1]

[1] Department of Science, McMaster University, Hamilton, Ontario, Canada L8S 4L8

*Corresponding Author: teodorag888@gmail.com

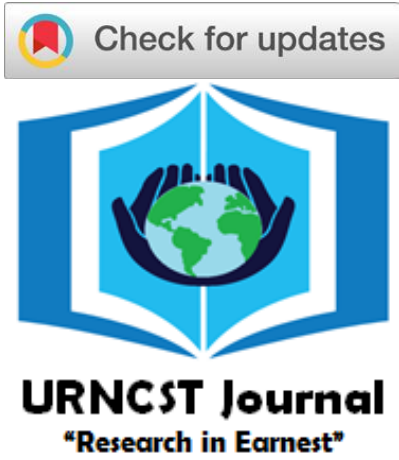

\begin{abstract}
Introduction: Monosodium Glutamate (MSG) is a widely used food additive to enhance flavours. Though commonly used, MSG's accumulation in the body can induce genomic instabilities. These genome instabilities are detectable through various methods such as Random Amplified Polymorphic DNA Polymerase Chain Reaction (RAPD-PCR) and comet assay. Additionally, cells can employ DNA repair mechanisms to ameliorate this damage. The objective of this review paper is to investigate the role of prolonged MSG ingestion in DNA damage, potential downstream diseases, and DNA repair mechanisms that cells undertake to counteract these effects, such as nucleotide excision repair (NER) and base excision repair (BER). Compounds such as vitamin C, green tea extract, and Allium sativum have been shown to ameliorate the health hazards of MSG by inhibiting oxidative stress, reducing apoptosis, and increasing antioxidant availability.

Methods: This literature review focuses on MSG-induced DNA damage mechanisms including gene suppression, chromosomal disruption, and carcinogenic effects. We conducted a comprehensive literature review of 28 peer-reviewed articles published since 2000-present.

Results: Studies show that MSG consumption may lead to the formation of Reactive Oxygen Species (ROS) and micronuclei $(\mathrm{MN})$, which are known as biomarkers of carcinogenesis. Furthermore, the genomic instabilities that lead to this effect were identified through the use of RAPD-PCR and comet assays. It is shown that these instabilities are mainly dealt with by endogenous repair machineries such as NER and BER. Also, researchers have identified many substances which act as preventative measures towards the potential harmful impacts of MSG.

Discussion: Diseases, such as cancer and obesity, may be linked to chronic intake of MSG. The efficacy of the mentioned DNA damage detection methods will be discussed. Furthermore, the endogenous mechanisms of NER and BER are outlined in this review. Substances such as vitamin C, green tea extract, and Allium sativum aid to prevent genotoxic effects induced by MSG.

Conclusion: Through this literature review, we hope to bring awareness to the harmful impacts of MSG on genome stability and its role in disease development. We aim to educate the public about the prevalent usage of MSG in the food industry and to inform individuals to take precautions in their food consumption.
\end{abstract}

Keywords: MSG; DNA damage; oxidative stress; micronuclei; chromosomal aberrations; RAPD-PCR; comet assay; BER; NER; preventative approaches

\section{Introduction}

Monosodium glutamate (MSG) is a widely used food additive which enhances the umami taste in foods [1]. Umami taste is strongly elicited by glutamic acid and glutamate, which are abundantly available in MSG-containing foods [2]. MSG has been associated with numerous forms of toxicity such as neurotoxicity, hepatotoxicity, and genotoxicity [3]. When MSG is accumulated in the body, it may lead to several diseases such as cancer, obesity, and diabetes [3, 4]. A randomized control trial (RCT) experiment shows that a chronic intake of MSG can induce a significant reduction in the perceived taste of umami [2]. Therefore, an increased demand for MSG is most apparent among those who

Aghaei et al. | URNCST Journal (2021): Volume 5, Issue 8

DOI Link: https://doi.org/10.26685/urnest.279 frequently consume it due to a strong desire for a higher intake of the compound [2]. The skeletal structure of MSG is shown in Figure 1.

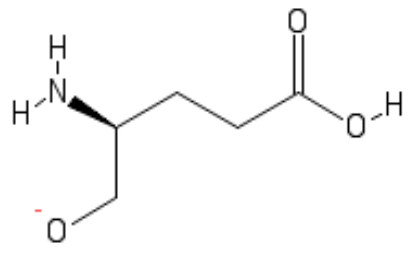

Figure 1. Skeletal structure of monosodium glutamate (MSG). 
UNDERGRADUATE RESEARCH IN NATURAL AND CLINICAL SCIENCE AND TECHNOLOGY (URNCST) JOURNAL Read more URNCST Journal articles and submit your own today at: $\underline{\text { https://www.urncst.com }}$

Once MSG has entered the body, it starts to break down rapidly without any enzymatic interventions which results in a spike in glutamate levels [5]. Glutamate is a compound with many physiological and pathological functions: it is a major substrate for enterocytes' energy production, precursor of $\mathrm{N}$-acetylglutamate (metabolic regulator), and an excitatory neurotransmitter in the central nervous system [5]. The average daily intake of MSG in developed countries is around $0.3-1.0 \mathrm{~g} / \mathrm{day}, 10.0 \mathrm{~g} /$ day in Germany while other countries in Europe average about $1.0 \mathrm{~g} / \mathrm{day}$ [3]. Additionally, Asian countries such as Japan have higher values of 1.1-1.6 g/day, 1.5-3.0 g/day in Taiwan, and 1.6-2.3 $\mathrm{g} /$ day in South Korea [3].

MSG exhibits deoxyribonucleic acid (DNA) damage in mammals. The preservation of the genomic sequence is crucial for perpetuating life [6]. DNA, the basic foundation of inheritance, is a reactive molecule that is highly susceptible to undergo endogenous and exogenous chemical modifications eventually leading to DNA damage. The purpose of this literature review is to explore the genotoxic effects of MSG consumption by analyzing its internal effects in the human body. Over the years, scientists have discovered various techniques to detect DNA damage. In this literature review, the accuracy of RAPD-PCR and comet assay techniques for examining DNA damage induced by MSG will be discussed. Moreover, the repair mechanisms and preventative approaches for reducing the occurrence of DNA damage caused by MSG will be outlined.

\section{Methods}

To produce this literature review, relevant empirical and review articles were retrieved from the following search engines/databases: PubMed, Google Scholar, and McMaster University Library. Research articles were selected based on the following inclusion criteria: (1) pertaining to the genotoxicity of MSG as well as the detection and repair of DNA damage in relation to MSG, (2) being peer-reviewed, and (3) being published after the year 2000. With respect to the type of peer-reviewed articles, 10 articles were empirical, and 17 articles were meta-analyses. Additionally, 1 book was used for extended research. Research articles on the genotoxicity of MSG, DNA damage mechanisms, and DNA repair mechanisms were obtained using the search engine keywords of "monosodium glutamate," "flavor enhancer," "mice," "rats," "umami substance," "toxicity," "effects," "obesity," "liver toxicity," "neurotoxicity," and "oxidative balance," "oxidative damage," "oxidative stress," "clinical studies," "genotoxicity," "health impact," "DNA damage," "chemical toxicology," "DNA repair," "methylation activity," "aberration," "carcinogenic," "DNA fragmentation," "comet assay," and "immunoassay," " "ameliorate," "dietary vitamins," "DNA methylation," "genome stability," "micronucleus," "preventative," "DNA damage repair," and "antioxidants." Research articles were found on the genotoxicity of MSG, DNA damage mechanisms, and DNA repair mechanisms. was used in The search engine used the following keywords: "monosodium glutamate," "flavor enhancer," "mice," "rats," "umami substance," "toxicity," "effects," "obesity," "liver toxicity," "neurotoxicity," and "oxidative balance," "oxidative damage," "oxidative stress," "clinical studies," "genotoxicity," "health impact," "DNA damage," "chemical toxicology," "DNA repair," "methylation activity," "aberration," "carcinogenic," "DNA fragmentation," "comet assay," and "immunoassay," “ "ameliorate," "dietary vitamins," "DNA methylation," "genome stability," "micronucleus," "preventative," "DNA damage repair," and "antioxidants." A total of 28 articles were found eligible and further analyzed.

\section{Results}

How MSG causes DNA damage

Reactive Oxygen Species Formation

MSG consumption results in its immediate metabolic breakdown followed by increased levels of glutamate [10]. It has been shown that excessive renal metabolism of MSG through chronic intake can act as a source of reactive oxygen species (ROS) [7]. ROS is known to be the major contributor to oxidative stress which can lead to functional damage to cellular DNA [7]. These damages result in a wide range of biological effects such as altered signal transduction pathways, defects in gene expression and translation, and apoptosis [8]. For example, in a recent study, Pavlovic et al. observed a significant increase in thymocyte apoptosis up to 14 days following the administration of MSG $(4 \mathrm{mg} / \mathrm{g}$ of body weight) [9].

MSG-induced DNA damage includes single and double stranded breaks, mutations, clumping and stickiness of chromosomes, genetic rearrangements, impaired excision repair machinery, and structural and numerical chromosomal aberrations (CA) [9-10]. The latter is considered a key biomarker for assessing cancer risk [9]. Several studies found that MSG consumption is related to increased CA frequency in human cell cultures, suggesting that MSG has genotoxic and cancerous effects on host cell genome [9-11].

\section{Micronucleus Formation}

Furthermore, another consequence of MSG-induced DNA damage has been identified. In vivo micronucleus and comet assays indicate micronucleus (MN) formation because of chronic MSG intake [10]. MN formation along with CA frequency are used as biomarkers to assess genotoxic effects of substances and evaluate cancer risks in humans [11]. A recent large international cohort study demonstrated a significant association between $\mathrm{MN}$ frequency and carcinogenesis [12]. Thus, it is possible that chronic MSG consumption is associated with increased MN formation frequency, which is highly prevalent amongst cancer patients. 
UNDERGRADUATE RESEARCH IN NATURAL AND CLINICAL SCIENCE AND TECHNOLOGY (URNCST) JOURNAL Read more URNCST Journal articles and submit your own today at: https://www.urncst.com

DNA Damage Detection Techniques

\section{$R A P D-P C R$}

Genome instabilities are detectable through various methods. RAPD-PCR has been shown to detect genotoxininduced DNA damage [9]. RAPD-PCR uses the amplification of genomic DNA along with primers obtained from random nucleotide sequences which bind to various regions of the genomic DNA. This generates amplicons of varied lengths, generally between 100-4000 base pairs, which is separated by gel electrophoresis, creating a DNA fingerprint [13]. Atienzar and colleagues initiated an experiment to evaluate the effects of varying types of genetic DNA damage on RAPD-PCR profiles. The results demonstrate that sonication, which is the disruption of DNA by exposure to high-frequency sound waves, caused greater changes in the RAPD-PCR profile patterns. Additionally, a sample of DNA treated with benzo[a]pyrene diol epoxide (BPDE), which is a mutagen, generated similar results with greater changes in the RAPD-PCR patterns by enhancing band intensity [13]. These results show that RAPD-PCR can detect DNA damage profiles. A study conducted by Ataseven et al. evaluated the genotoxic effects of MSG by detecting DNA damage using RAPD-PCR in cultured human lymphocytes. The results show that RAPD-PCR detected pattern difference within the band intensity, indicating DNA damage [9]. This study suggests that intensity of the RAPDPCR bands correlates with DNA damage, mutations, or chromosomal rearrangements [9]. This is the first study providing evidence that the RAPD-PCR technique helps detect genotoxic effects of MSG on cultured human lymphocytes.

\section{Comet Assay}

The comet assay is a widely used tool to measure DNA breaks through single gel electrophoresis as it is sensitive to genotoxicity, mutagenicity, and carcinogenicity of toxic chemicals [9]. In this technique, the broken DNA fragments separate from the intact DNA sequence, forming a comet that can be quantified by microscopy [14]. A review conducted by Collins analyzed how oxidative DNA breaks is measurable through comet assay, and its significances [15]. The paper shows how the comet assay can be used to monitor the repair of strand breaks in vitro or at the cellular level. A review by Ataseven et al. evaluated the genotoxic effects of MSG by detecting DNA damage using comet assay. This paper demonstrates that comet assay is an accelerated method for measuring DNA breaks at the cellular level [9]. An alternative review authored by Gonzalez-Hunt et al. describes how the comet assay has advanced this technique through the combination of other methods, such as fluorescence in situ hybridization (FISH) [14]. Comet-FISH is an approach used to quantify relevant low levels of DNA damage/lesions with sequence specificity [16]. Comet-FISH is advantageous as this method can detect DNA breaks at the

Aghaei et al. | URNCST Journal (2021): Volume 5, Issue 8

DOI Link: https://doi.org/10.26685/urncst.279 level of the DNA strand [14]. Overall, comet assay helped evaluate the DNA breaks of MSG on human lymphocytes.

\section{Endogenous Repair Mechanisms for DNA Damage $N E R$ and BER}

In human cells, the predominant repair process for removing oxidative DNA lesions is via NER and BER [17]. The most abundant oxidative DNA lesion amongst mammals is 7,8-dihydro-8-oxoguanine (8-oxoG) [18]. This common lesion is repaired via the BER pathway [18]. Research reveals that BER involves the activity of glycosylase, which aids in cleaving out the mutated single base and replacing it with the appropriate undamaged base [19]. It has been reported that OGG1 is the glycosylase responsible for the repair of 8-oxoG [18]. Researchers report that the impairment of glycosylases in the nucleus can initiate the response of NER to act as a 'backup' mechanism to perform the functions of BER [18]. The NER and BER pathways work in a collaborative manner in response to oxidative DNA damage [18]. NER proteins (XPA, XPC, XPG, CSA, CSB and UV-DDB) can work together to stimulate glycosylase [20]. Once glycosylase is stimulated, this initiates the BER pathway, where DNA glycosylase cleaves the glycosidic bond, thereby freeing the oxidative lesion [20].

Preventative Approaches That Combat DNA Damage

Researchers Farombi and Onyema investigated the modulatory effects of dietary antioxidant vitamin $\mathrm{C}, \mathrm{E}$ and quercetin on MSG-induced oxidative damage in the liver, kidney and brain of rat subjects [21]. MSG dosages were administered to the rats at $4 \mathrm{mg} / \mathrm{g}$ (per body weight) to increase the formation of malondialdehyde (MDA), a naturally occurring marker of oxidative stress, in the liver, kidney, and brain [21]. The results demonstrated that the administration of vitamin $\mathrm{C}, \mathrm{E}$, and quercetin to the MSGtreated rats significantly reduced the MDA levels. The results also state that vitamin $\mathrm{C}$ and quercetin protected against MSG-induced genotoxicity, however, vitamin $\mathrm{E}$ failed to do so. Another study conducted by Waiz et al. showed that MSG doses of $6 \mathrm{mg} / \mathrm{g}$ (per body weight) for 10 consecutive days promoted hepatotoxicity and oxidative stress in rats [22]. When vitamin C $(500 \mathrm{mg} / \mathrm{kg}$ per body weight) was administered with MSG, a significant reduction in oxidative stress and hepatic toxicity was observed [22].

Moreover, it has been reported that green tea extract (GTE) can ameliorate MSG-induced obesity by reducing insulin and leptin concentrations in rats [12]. Additionally, due to the antioxidant properties in GTE, green tea has the ability to reduce the production of ROS produced by MSG.

Furthermore, recent research has proposed the ingestion of Allium sativum (garlic) as a neuroprotective agent against MSG-induced neurotoxicity [23]. The study revealed that MSG significantly affects short-term spatial memory in rats due to oxidative stress and induces apoptosis in the brain tissue. It was observed that Allium sativum improved MSG- 
UNDERGRADUATE RESEARCH IN NATURAL AND CLINICAL SCIENCE AND TECHNOLOGY (URNCST) JOURNAL Read more URNCST Journal articles and submit your own today at: https://www.urncst.com

induced degenerative and apoptotic changes in the brain tissue by reducing the oxidative stress in the hippocampus by increasing the expression of $\mathrm{Ki}-67$, a protein marker that indicates the active sites of neurogenesis in the brain [23].

\section{Discussion \\ Diseases Linked to The Genotoxic Effects of MSG}

MSG consumption is thought to be associated with various diet-related diseases such as obesity, diabetes, metabolic disorders, and carcinogenesis [26, 1]. Studies on neonatal mice have shown that MSG consumption may set a precedent for the development of obesity [1]. As previously discussed, MSG disrupts the glutamate levels which can further lead to impaired metabolic functions and eventually obesity and diabetes [3]. Thus, according to studies on rats, appropriate dieting at early stages in life may play a crucial role in avoiding the development of diabetes later in life. Carcinogenesis is another notable side-effect of chronic MSG consumption [10]. In addition to the production of ROS, MSG can also lead to increased MN frequency and chromosomal abnormalities [9]. The undesirable effects of MSG are considered valid biomarkers of carcinogenesis among experts [9]. Despite the presence of evidence for these effects, further randomized control trial studies are required to solidify the relationship between MSG and carcinogenesis.

\section{Methods for Detecting DNA Damage Caused by MSG}

Multiple DNA detection methods, such as RAPD-PCR and comet assay, have become standard techniques for evaluating DNA damage. A systematic review conducted by Imam looked at the potential genotoxic effects of MSG using RAPD-PCR and comet assay in cultured human lymphocytes. This paper is closely related to the study conducted by Ataseven et al. which evaluated the genotoxic effects of MSG using these two assays. Both studies showed how RAPD-PCR detects DNA damage, as suggested by band intensity changes. Additionally, through the comet assay, both studies demonstrated how the additive MSG caused DNA damage regardless of the concentration [9, 24]. Taken together, comet assay and RAPD-PCR are used to measure MSG-induced DNA damage which can be an important biomarker on human health.

The comet assay has applications in assessing genotoxicity, detecting contamination of genotoxins within the environment, and human biomonitoring within eukaryotic cells [26]. Research studies have shown further improvements to this technique. A study conducted by Angelis et al. demonstrated that if nucleoids are incubated with bacterial repair endonucleases, the specificity of the comet assay will be significantly improved. This is because bacterial repair endonuclease recognizes specific types of damage and makes the DNA more pronounced, extending the range of DNA damage which can be detected [26]. The comet assay is suited for human investigation; however, during examinations there are some limitations. For

Aghaei et al. | URNCST Journal (2021): Volume 5, Issue 8 DOI Link: https://doi.org/10.26685/urncst.279 example, human tissue can be removed for inspection of DNA damage, but the essential control tissue from a healthy human is harder to obtain [26]. In general, comet assay has become a well-established method for detecting DNA breaks in a single cell as it is sensitive, simple, and rapid [26].

RAPD-PCR has the potential to detect several kinds of DNA damage as well as mutations, allowing for applications such as detection of genotoxicity and carcinogenesis [13]. RAPD-PCR displays several advantages in comparison to more conventional methods. For example, this technique is significantly cost-effective as it does not require the use of specialized equipment. Similar to other methods, RAPDPCR has some limitations. One of the limitations to this technique is the difficulty to estimate or differentiate the contribution of DNA damage and mutations [13]. DNA damage is only detected based on changes in RAPD-PCR profiles, but the profiles do not distinguish different types of damage.

Despite the great advances this field has made in genotoxicity, there are still some drawbacks that must be considered. A common problem associated with these methods is their efficiency under certain applications. For example, RAPD-PCR is less effective particularly after pollution accidents [13]. A beneficial strategy could be to look at RAPD-PCR profiles in comparison to other quantitative genotoxicity assays including comet assay. This is advantageous because RAPD-PCR is a qualitative or semiquantitative method. Therefore, when combined with comet assay, which is a quantitative method, results will be significantly more accurate when detecting DNA damage $[13,15]$.

Mechanisms that Repair MSG-induced DNA Damage

On a regular basis, living organisms are exposed to a wide variety of DNA damaging agents that can heavily impact health and prompt diseases. Through decades of research, scientists are now able to recognize the intricate capabilities embedded within cells. Complex systems, such as DNA repair mechanisms, reduce the detrimental consequences of DNA damage. NER and BER are two mechanisms that repair ROS-induced DNA damage [26]. Substantial evidence indicates that both BER and NER work together to alleviate genotoxic stress by providing repair pathways and utilizing the complementary DNA strand to restore sequence information lost in the damaged DNA strand [26]. Considerable evidence alludes to the role of XPC in NER and BER in DNA repair-pathways. Evidence supports that this protein has a high affinity for DNA and can scan deformities embedded in the double helix [18]. Min and Pavletich demonstrate that XPC binds to opposing ends of the DNA lesion and inverts the damaged bases out of the helical structure, which can explain the response NER generates during the damage recognition process [27]. 
UNDERGRADUATE RESEARCH IN NATURAL AND CLINICAL SCIENCE AND TECHNOLOGY (URNCST) JOURNAL Read more URNCST Journal articles and submit your own today at: https://www.urncst.com

Natural Products that Prevent DNA Damage from MSG

Toxicity

This review provides some insight on the protective roles of medicinal compounds and their active role against MSG-induced toxicity. Such natural products include vitamin C, GTE, and Allium sativum.

\section{Vitamin $C$}

Vitamin C (ascorbic acid) is an essential water-soluble nutrient which exerts a protective role as a physiological antioxidant [8]. This vitamin has demonstrated a protective role in MSG-cytotoxicity by upregulating the expression of intracellular $\mathrm{Bcl}-2$, which is an antioxidant protein that protects against apoptosis [8]. The overexpression of Bcl-2 allows cells to cope with the effects of ROS, by increasing endogenous antioxidant enzymes. By removing the ROS, antioxidants can reverse the ROS-induced decline in Bcl-2 and prevent cell death [8].

\section{Green Tea Extract}

Leptin is the most abundant peptide in adipose tissue of mammals [28]. However, in obese patients, leptin levels cannot enter the cerebral spinal fluid to reach the hypothalamus to regulate appetite [28]. This may result in a phenomenon referred to as "leptin resistance" [28]. As MSG may play a role in obesity, it is possible that this additive interferes with leptin levels in these patients. Future research is needed to further explore this possibility. Green tea extract has been observed to play a role in reducing insulin and leptin concentrations in obese rat subjects [22]. The supplementation of green tea extract can stabilize glucose and leptin levels to improve liver and kidney toxicity induced by MSG [22].

\section{Allium Sativum}

Garlic, Allium sativum, contains various biological sulfur compounds, such as diallyl disulphide (DAD) and diallyl trisulfide (DAT), which give it its distinctive neuroprotective properties. Due to its nutraceutical effects, garlic can diminish toxic effects in the brain. This compound has been linked to ameliorating cognitive and brain impairments due to ROS by exhibiting antioxidant properties that act as an antiseptic against MSG-induced toxicity [23].

\section{Conclusions}

Overall, this literature review explores the damaging effects of MSG on DNA and the various endogenous pathways the body utilizes and the preventative approaches to combat these effects. With the rise of food additives, such as MSG, DNA damage is expected to become more prominent [4]. This review encompasses the genotoxicity of MSG, the various methods to detect and repair DNA damage induced by MSG, and natural compounds that prevent DNA damage from occurring. Compounds such as vitamin C, GTE, and Allium sativum have been shown to ameliorate the health hazards of MSG by inhibiting oxidative stress,

Aghaei et al. | URNCST Journal (2021): Volume 5, Issue 8

DOI Link: https://doi.org/10.26685/urnest.279 reducing apoptosis, and increasing antioxidant availability. Although this review provides further advances to this field, certain limitations are important to consider. For instance, many of the primary literatures assessed lacked control groups which diminished the accuracy of the obtained results. All the papers analyzed in this review used different doses of MSG intake leading to a large discrepancy between the mean values. Extremely high concentrations of MSG may represent unrealistic diets that may lead to exaggerated health effects. Majority of the primary articles used cultured cells and in-vivo administrations in rats to study the effects of MSG, thus there is a lack of research involving human trials. It is encouraged that food and health regulators monitor the distribution of MSG in food products as its chronic intake can lead to serious health implications. Finally, the adverse health effects mentioned in this paper solely focus on the chronic intake of MSG, however, further research is required to investigate the effects of non-chronic ingestion.

\section{List of Abbreviations Used}

MSG: monosodium glutamate

RCT: random control trial

DNA: deoxyribonucleic acid

ROS: reactive oxygen species

CA: chromosomal aberrations

$\mathrm{MN}$ : micronucleus

RAPD-PCR: random amplified polymorphic DNA

polymerase chain reaction

BPDE: benzo[a]pyrene diol epoxide

FISH: fluorescence in situ hybridization

NER: nucleotide excision repair

BER: base excision repair

8-oxoG: 7,8-dihydro-8-oxoguanine

MDA: malondialdehyde

GTE: green tea extract

DAD: diallyl disulphide

DAT: diallyl trisulfide

\section{Conflicts of Interest}

The authors have no conflicts of interest to disclose.

Ethics Approval and/or Participant Consent

No ethical approvals were needed in conducting this literature review.

\section{Authors' Contributions}

NA: made contributions to the design of the study, collected and analysed data, drafted the manuscript, and gave final approval of the version to be published.

TG: contributed to study design and planning, assisted with the collection and analysis of data, and gave final approval of the version to be published.

NK: made substantial contributions to the design of the study, the collection of data as well as interpretation and 
UNDERGRADUATE RESEARCH IN NATURAL AND CLINICAL SCIENCE AND TECHNOLOGY (URNCST) JOURNAL Read more URNCST Journal articles and submit your own today at: https://www.urncst.com

analysis of the data, revised the manuscript critically, and gave final approval of the version to be published.

\section{Acknowledgements}

We would like to thank Yangyang Jiang for her contributions in editing our manuscript, assisting in organizing the layout of the paper, and providing strong feedback.

\section{Funding}

This study was not funded.

\section{References}

[1] Niaz K, Zaplatic E, Spoor J. Extensive use of monosodium glutamate: A threat to public health? Experimental and Clinical Sciences Journal. 2018;17:273-278. https://doi.org/10.17179/excli20181092

[2] Noel CA, Finlayson G, Dando R. Prolonged exposure to monosodium glutamate in healthy young adults decreases perceived umami taste and diminishes appetite for savory foods. Journal of Nutrition. 2018;148(6):980-988. https://doi.org/10.1093/jn/nxy055

[3] Hajhasani M, Soheili V, Zirak MR, Sahebkar AH, Shakeri A. Natural products as safeguards against monosodium glutamate-induced toxicity. Iranian Journal of Basic Medical Sciences. 2020;23(4):416-30. https://doi.org/10.22038/ijbms.2020.43060.10123

[4] Pongking T, Haonon O, Dangtakot R, Onsurathum S, Jusakul A, Intuyod K, et al. A combination of monosodium glutamate and high-fat and high-fructose diets increases the risk of kidney injury, gut dysbiosis and host-microbial co-metabolism. PLOS ONE. 2020;15(4). https://doi.org/10.1371/journal.pone.0231237

[5] Zanfirescu A, Ungurianu A, Tsatsakis AM, NiEulescu GM, Kouretas D, Veskoukis A, et al. A review of the alleged health hazards of monosodium glutamate. Comprehensive Reviews in Food Science and Food Safety. 2019;18(4):1111-1124. https://doi.org/ 10.1111/1541-4337.12448

[6] Wang J, Lindahl T. Maintenance of genomic stability. Genomics Proteomics Bioinformatics. 2016;14(3):119121. https://doi.org/10.1016/j.gpb.2016.06.001

[7] Sharma A. Monosodium glutamate-induced oxidative kidney damage and possible mechanisms: A minireview. Journal of Biomedical Science. 2015. https://doi.org/10.1186/s12929-015-0192-5

[8] Pavlovic V, Pavlovic D, Kocic G, Sokolovic D, Jevtovic-Stoimenov T, Cekic S, et al. Effect of monosodium glutamate on oxidative stress and apoptosis in rat thymus. Molecular and Cellular Biochemistry. 2007 Sep 1;303(1-2):161-166. https://doi.org/10.1007/s11010-007-9469-7
[9] Ataseven N, Yüzbaşıŏlu D, Keskin AÇ, Ünal F. Genotoxicity of monosodium glutamate. Food and Chemical Toxicology. 2016 May 1;91:8-18. https://doi.org/10.1016/j.fct.2016.02.021

[10] Imam RS. Genotoxicity of monosodium glutamate: A review on its causes, consequences and prevention. Indian Journal of Pharmaceutical Education and Research. 2019;53(4):S510-517. https://doi.org/ 10.5530/ijper.53.4s.145

[11] Giannattasio M, Lazzaro F, Longhese MP, Plevani P, Muzi-Falconi M. Physical and functional interactions between nucleotide excision repair and DNA damage checkpoint. The EMBO Journal. 2004 Jan;23(2):429 38. https://doi.org/10.1038/sj.emboj.7600051

[12] Bonassi S, El-Zein R, Bolognesi C, Fenech M. Micronuclei frequency in peripheral blood lymphocytes and cancer risk: Evidence from human studies. Mutagenesis. 2011 Jan;26(1):93-100. https://doi.org/10.1093/mutage/geq075

[13] Atienzar FA, Venier P, Jha AN, Depledge MH. Evaluation of the random amplified polymorphic DNA (RAPD) assay for the detection of DNA damage and mutations. MutRes-Genetic Toxicology and Environmental Mutagenesis. 2002 Jan;521(1):151163. https://doi.org/10.1016/S1383-5718(02)00216-4

[14] Gonzalez-Hunt CP, Wadhwa M, Sanders LH. DNA damage by oxidative stress: Measurement strategies for two genomes. Current Opinion in Toxicology. 2018 Feb 1;7:87-94. https://doi.org/10.1016/j.cotox .2017.11.001

[15] Collins AR. Measuring oxidative damage to DNA and its repair with the comet assay. BBA - General Subjects. 2014 Feb 1;1840(2):794-800. https://doi.org/ 10.1016/j.bbagen.2013.04.022

[16] Mondal M, Guo J. Comet-FISH for ultrasensitive strand-specific detection of DNA damage in single cells. Methods in Enzymology. 2017;591:83-95. https://doi.org/10.1016/bs.mie.2017.03.023

[17] Schaerer OD. Nucleotide excision repair in eukaryotes. Cold Spring Harbor Perspectives in Biology. 2013;5(10). https://doi.org/10.1101/cshperspect.a012609

[18] Melis JPM, Steeg H, Luijten M. Oxidative DNA damage and nucleotide excision repair. Antioxidants \& Redox Signaling. 2013 Jun;18(18):24019-2419. https://doi.org/10.1089/ars.2012.5036

[19] Cooke MS, Evans MD, Dizdaroglu M, Lunec J. Oxidative DNA damage: Mechanisms, mutation, and disease. Federation of American Societies for Experimental Biology. 2003 Jul;7(10):1195-214. https://doi.org/10.1096/fj.02-0752rev

[20] Kumar N, Raja S, Van Houten B. The involvement of nucleotide excision repair proteins in the removal of oxidative DNA damage. 2020 Nov;48(20):1122711243. https://doi.org/10.1093/nar/gkaa777 
UNDERGRADUATE RESEARCH IN NATURAL AND CLINICAL SCIENCE AND TECHNOLOGY (URNCST) JOURNAL Read more URNCST Journal articles and submit your own today at: https://www.urncst.com

[21] Farombi EO, Onyema OO. Monosodium glutamateinduced oxidative damage and genotoxicity in the rat: Modulatory role of vitamin C, vitamin E and quercetin. Human \& Experimental Toxicology. 2006

May;25(5):251-259. https://doi.org/10.1191/0960327106ht621oa

[22] Waiz SA, Raies-ul-Haq M, Waiz HA, Gupta S, Pathak AK. Preliminary study on the protective effect of vitamin $\mathrm{C}$ on monosodium glutamate-induced hepatotoxicity in rats. Comparative Clinical Pathology. 2010 Aug;24:1063-1068. https://doi.org/10.1007/ s00280-010-1418-6

[23] Hazzaa SM, Abdelaziz SAM, Eldaim MAA, AbdelDaim MM, Elgarawany G. Neuroprotective potential of allium sativum against monosodium glutamateinduced excitotoxicity: Impact on short-term memory, gliosis, and oxidative stress. Nutrients. 2020;12;1-17. https://doi.org/10.3390/nu12041028

[24] Sarfaraz S, Kumar J. Effects of monosodium glutamate on drosophila melanogaster. Brivibas Gatve, Germany: LAP LAMBERT Academic Publishing, 2014 \#25.
[25] Nakanishi Y, Tsuneyama K, Fujimoto M, Salunga TL, Nomoto K, An J-L, et al. Monosodium glutamate (MSG): A villain and promoter of liver inflammation and dysplasia. Journal of Autoimmunity. 2008 Jan 1;30(1):42-50. https://doi.org/10.1016/i.jaut.2007.11 .016

[26] Ock C-Y, Kim E-H, Choi DJ, Lee HJ, Hahm K-B, Chung MH. 8-hydroxydeoxyguanosine: Not mere biomarker for oxidative stress, but remedy for oxidative stress-implicated gastrointestinal diseases. World Journal of Gastroenterology. 2012 Jan 28;18(4):302-8. https://doi.org/10.3748/wjg.v18.i4.302

[27] Min JH, Pavletich NP. Recognition of DNA damage by the Rad4 nucleotide excision repair protein. Nature. 2007;449:570-575. https://doi.org/10.1016/j.bbagen .2013 .04 .022

[28] Paracchini V, Paola P, Emanuela T. Genetics of leptin and obesity: A huge review. American Journal of Epidemiology. 2005 Jul 15;162(2):101. https://doi.org/10.1093/aje/kwi174

\section{Article Information}

Managing Editor: Jeremy Y. Ng

Peer Reviewers: Yangyang Jiang, Katelyn Sushko

Article Dates: Received May 08 21; Accepted Jul 10 21; Published Aug 0421

\section{Citation}

Please cite this article as follows:

Aghaei N, Grigorescu T, Katani N. Investigating DNA damage mechanism induced by monosodium glutamate and associated DNA repair cell machinery: A literature review. URNCST Journal. 2021 Aug 04: 5(8).

https://urncst.com/index.php/urncst/article/view/279

DOI Link: https://doi.org/10.26685/urncst.279

\section{Copyright}

(C) Novin Aghaei, Teodora Grigorescu, Niayesh Katani. (2021). Published first in the Undergraduate Research in Natural and Clinical Science and Technology (URNCST) Journal. This is an open access article distributed under the terms of the Creative Commons Attribution License (https://creativecommons.org/licenses/by/4.0/), which permits unrestricted use, distribution, and reproduction in any medium, provided the original work, first published in the Undergraduate Research in Natural and Clinical Science and Technology (URNCST) Journal, is properly cited. The complete bibliographic information, a link to the original publication on http://www.urncst.com, as well as this copyright and license information must be included.
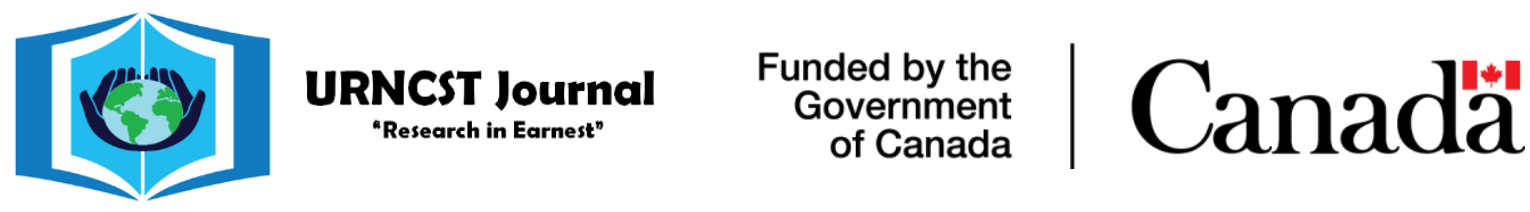

Do you research in earnest? Submit your next undergraduate research article to the URNCST Journal!

| Open Access | Peer-Reviewed | Rapid Turnaround Time | International |

| Broad and Multidisciplinary | Indexed | Innovative | Social Media Promoted |

Pre-submission inquiries? Send us an email at info@ urncst.com | Facebook, Twitter and LinkedIn: @URNCST

Submit YOUR manuscript today at https://www.urncst.com! 